\title{
The Fate of Fatty Compounds and Surfactants Used as Sucker Control Agents on Field Tobacco*
}

\author{
by T. C. Tso and H. Chu \\ Beltsville Agricultural Researdh Center, Northeastern Region, \\ Agricultural Research Service, U.S. Department of Agriculture, Beltsville, Maryland, U.S.A.
}

\section{INTRODUCTION}

Fatty acid derivatives mixed with various surfactants have been shown to be effective sudker inhibition agents for field tobacco $(1,2,7,8)$. The residual levels of these compounds are rather difficult to determine, because these fatty compounds occur naturally in tobacco (3), and also because they may interconvert after field application onto tobacco plants. This paper reports two topics studied:

[1] the possible interconversion among fatty acids, alcohols, and esters when used individually or in combination as suckering agents;

[2] the possible breakdown of surfactants.

The effectiveness of sudker inhibition of various fatty acid derivatives with different carbon chain length was reported previously $(1,2)$. The pattern of carbon chain length and relative effectiveness for fatty esters is similar to patterns of fatty alcohols. The $\mathrm{C}-8$ to $\mathrm{C}-14$ materials are all effective for sucker inhibition, and the $\mathrm{C}-10$ is the most effective. Furthermore, fatty alcohols are more effective than corresponding esters. Sucker inhibition appears to be caused mainly when fatty compounds contact and destroy differentiating plant cells. Previous tests with lauric acid${ }^{1-14} \mathrm{C}$ methyl ester showed that such an inhibition is localized at the axillary bud area, and that ${ }^{14} \mathrm{C}$-activity decreases with time, indicating a loss and/or conversion of the applied compound (5).

Surfactants used with fatty compounds are either Tween 20 (polyoxyethylene[20]sorbitan monolaurate), or Tween 80 (polyoxyethylene[20]sorbitan monooleate). Tween 20 is usually used with methyl caprate, and Tween 80 with the alcohols. The Tween surfactants are non-ionic, surface-active, partial-ester types of emulsifiers produced by condensing ethylene oxide with sorbitan fatty acids. The fatty acid moiety of the Tween materials could probably contribute to the residue level of fatty compounds of treated tobacco.

\footnotetext{
- Received for publication: 10th May, 1976.

Mention of a trademark or proprietary product does not constitute a guarantee or warranty of the producr by the U. S. Department of Agriculture and does not imply its approval to the exclusion of ocher products that may also be suitable.
}

In this study, we used lauric acid derivatives to examine their fate and possible interconversion. ${ }^{14} \mathrm{C}$-labeled lauric acid materials were the only ones readily available. For surfactants, we used both ${ }^{14} \mathrm{C}$-labeled Tween 20 and Tween 80 materials. The ${ }^{14} \mathrm{C}$-labeling for Tween was either at the ethylene-oxide position or at the fatty-acid position.

\section{MATERIALS AND METHODS}

\section{Test Plants and Field Treatments}

Field-grown plants of Nicotiana tabacum L. cv. Maryland Catterton were used for this experiment. The plants were produced under cultural conditions usual for Maryland tobacco. When the plants reached flowering stage, they were topped before test chemicals were applied.

Each topped plant was treated separately. The spray was applied with a laboratory aerosol dispenser and aimed directly onto the top center of the experimental plant with fine droplets and at a slow speed. The spray material ran down along the stalk and contacted the axillary buds with minimum loss. For studies of the interconversion of fatty compounds, green plants were used. One plant from each treatment was harvested and analyzed 16 hours after treatment, and another plant 144 hours after treatment. For Tween material studies, air-cured tobacco leaves were used. The reason for our not examining the Tween surfactants on fresh leaves was that facilities for the analysis of Tween were not available at the time of harvest.

\section{Preparation of Spray Solutions and \\ Chemical Analysis for Interconversion Studies}

${ }^{14} \mathrm{C}$-labeled lauric acid, alcohol, and ester were used for the interconversion study. Each labeled compound was diluted with non-labeled compound and then combined with one of the other three compounds, totalling nine spray solutions. Six of these solutions included a mixture of two compounds from either the acid, alcohol, or ester. The radioactive compounds were lauric acid-1${ }^{14} \mathrm{C}$, lauryl alcohol-1-14 $\mathrm{C}$, and lauric acid-1-14 $\mathrm{C}$ methyl ester. Each spray solution was prepared to contain $2.8 \mathrm{~g}$ 
Table 1. Composition of spray solutions for Interconversion teste.

\begin{tabular}{|c|c|c|}
\hline$A^{*}$ & $\mathrm{~B}^{*}$ & $\underline{C}^{*}$ \\
\hline $\begin{array}{c}0.4 \mathrm{~g} \\
\text { Tween } 20\end{array}$ & $\begin{array}{c}0.4 \mathrm{~g} \\
\text { Tween } 20\end{array}$ & $\begin{array}{c}0.4 \mathrm{~g} \\
\text { Tween } 20\end{array}$ \\
\hline $\begin{array}{c}0.7 \mathrm{~g} \\
\text { lauric acid }\end{array}$ & $\begin{array}{l}0.7 \text { g lauryl } \\
\text { alcohol }\end{array}$ & $\begin{array}{c}0.7 \mathrm{~g} \text { methyl } \\
\text { laurate }\end{array}$ \\
\hline $\begin{array}{c}8.33 \mu \mathrm{Cl} \\
{ }^{14} \mathrm{C}-1 \text {-lauric } \\
\text { acid } \\
20 \mathrm{ml} \mathrm{H}_{2} \mathrm{O}\end{array}$ & $\begin{array}{c}8.33 \mu \mathrm{Ci} \\
{ }^{14} \mathrm{C}-1 \text {-lauryl } \\
\text { alcohol } \\
20 \mathrm{ml} \mathrm{H}_{2} \mathrm{O}\end{array}$ & $\begin{array}{c}8.33 \mu \mathrm{Ci} \\
{ }^{14} \mathrm{C}-1 \text {-lauric } \\
\text { acid methyi } \\
\text { ester } \\
20 \mathrm{ml} \mathrm{H}{ }_{2} \mathrm{O}\end{array}$ \\
\hline
\end{tabular}

\begin{tabular}{|c|c|c|c|c|}
\hline A. & $\begin{array}{l}1.2 \mathrm{~g} \text { Tween } 20 \\
2.1 \mathrm{~g} \text { lauric acid } \\
10 \mathrm{ml} \mathrm{H} \mathrm{O}\end{array}$ & $\mathbf{A} \underline{A}^{*}$ & $A \underline{B}^{*}$ & $A \underline{C}^{*}$ \\
\hline B. & $\begin{array}{l}1.2 \mathrm{~g} \text { Tween } 20 \\
2.1 \mathrm{~g} \text { lauryl } \\
\text { alcohol } \\
10 \mathrm{ml} \mathrm{H} \mathrm{H}_{2} \mathrm{O}\end{array}$ & $B \underline{A}^{*}$ & $\mathrm{~B}$ B & $B \underline{C}^{*}$ \\
\hline c. & $\begin{array}{l}1.2 \mathrm{~g} \text { Tween } 20 \\
2.1 \mathrm{~g} \text { methyl } \\
\text { laurate } \\
10 \mathrm{ml} \mathrm{H} \mathrm{O}\end{array}$ & $C \underline{A}^{*}$ & $\mathrm{C} \underline{\mathrm{B}}^{*}$ & $\mathrm{C} \underline{\mathrm{C}}^{*}$ \\
\hline
\end{tabular}

* Radloactive

of total combined lauryl alcohol, acid, and/or ester and $1.6 \mathrm{~g}$ 'Tween 20 and to consist of $8.33 \mu \mathrm{Ci}$ of ${ }^{14} \mathrm{C}$-activity in a $30 \mathrm{ml}$ volume. Each solution was used for the treatment of two plants, or $15 \mathrm{ml}$ per plant. Details of the composition are shown in Table 1.

Only those plant parts exposed to spraying were analyzed. They included the whole stalk, top leaves, and interior center sections of lower plant leaves. The fresh material was chopped into small pieces and extracted for 10 min with a Waring Blendor, so that the final suspension was $70 \%$ ethanol (assuming the green plants contained $90 \% \mathrm{H}_{2} \mathrm{O}$ ). After filtration and volume measurement, a $100 \mathrm{ml}$ sample was evaporated at $30^{\circ} \mathrm{C}$ under reduced pressure to remove the alcohol. This water suspension was diluted with $50 \mathrm{ml}$ saturated aqueous $\mathrm{NaCl}$ and extracted with ether, and the ether extract was transferred to $10 \mathrm{ml}$ heptane for separation into acid, alcohol, and ester fractions.

One milliliter of the heptane solution, $5 \mathrm{ml}$ absolute ethanol, and $10 \mathrm{ml} 5 \% \mathrm{NaHCO}_{3}$ were shaken for $1 \mathrm{~min}$ and extracted three times with petroleum ether. (Without the presence of ethanol, lauric acid tended to be dispersed between the two phases.) After this process, the aqueous phase was evaporated to remove the ethanol present and then purified of possible residual amounts of lauryl alcohol by one more petroleum ether extraction, which was discarded. This aqueous fraction was reserved for the recovery of lauric acid. The petroleum ether extracts were evaporated to $0.2 \mathrm{ml}$ and saponified for $1 \mathrm{~h}$ with $5 \mathrm{ml} 0.5 \mathrm{~N} \mathrm{KOH}$. After the addition of $5 \mathrm{ml}$ distilled water, the alcohol fraction was extracted into petroleum ether. The aqueous phases of both the saponification mixture and the $\mathrm{NaHCO}_{3}$ mixture were acidified and extracted with petroleum ether to recover the ester and acid fractions, respectively. The ester fraction was analyzed as the corresponding acid. Each of the petroleum ether extracts was transferred to $1 \mathrm{ml}$ heptane, from which $0.1 \mathrm{ml}$ was removed for scintillation counting in a toluene cocktail. The resulting counts corresponded to $1 \mathrm{ml}$ of the original ethanol extract.

To verify the completeness of chemical separation, samples containing known amounts of standard lauryl alcohol, lauric acid, and methyl laurate, about $0.3 \mathrm{mg}$ each, were added to duplicate samples of $5 \mathrm{~g}$ dry cured tobacco. Both samples were left in closed containers overnight. Later they were extracted in a Waring Blendor and separated by the method described above. Identical samples of the mixture of standard alcohol, acid, and ester were separated by the same method without first being added to and recovered from tobacco. All resulting fractions were analyzed by gas chromatography, revealing no cross-contamination among fractions.

\section{Preparation of Spray Solutions and Analysis of Tween Materials}

Both ${ }^{14} \mathrm{C}$-labeled and regular Tween compounds were used in this study with fatty ester and alcohol. Methyl laurate was used with Tween 20 (6:2), and lauryl alcohol was used with Tween 80 (5:3). The Tween 20 and $T$ ween 80 compounds were either not labeled or labeled as ${ }^{14} \mathrm{C}-1$-fatty acid or as ${ }^{14} \mathrm{C}$-U-ethylene oxide. For ${ }^{14} \mathrm{C}$-labeled material, each plant received $25 \mu \mathrm{Ci}$ of activity. A hand-suckered control was included in this test to determine possible "badkground" interference.

Treated plants were harvested and cured in a conventional tobacco barn. The air-cured tobacco samples were ground into powder and analyzed at the ICI United States, Inc., chemical laboratory (9). Briefly, tobacco samples were extracted with a ternary mixture of ethyl acetate, ethanol, and water. Ethanol was removed, and the residue was partitioned between ethyl acetate and water. The Tween free-polyol moiety was extracted into a water layer, whereas the Tween esters remained in the ethyl acetate layer. After purification, the ester fraction was saponified by refluxing with $\mathrm{HCl}$ and extracting with hexane. The final purified Tween free polyol and Tween esters were measured with a colorimeter (9).

\section{RESULTS AND DISCUSSION}

\section{Interconversion among Acid, Alcobol, and Ester}

The ${ }^{14} \mathrm{C}$-activity of the recovered acid, alcohol, and ester fractions of fresh leaf samples, 16 and 144 hours after application from nine different treatments, were measured and are listed in Table 2.

When lauric acid (AA) was used, 98-99\% of the residue remained in the acid fraction, less than $1 \%$ changed to the alcohol or to ester fraction. Mixed application of acid with alcohol or ester (BA and $\mathrm{CA}$ ) did not change the general conversion pattern although much higher ester and alcohol levels were observed. That results from 16 hours or 144 hours were statistically similar indicated no further changes 16 hours after treatment. 


\begin{tabular}{|c|c|c|c|c|c|c|c|c|c|}
\hline \multirow{2}{*}{\multicolumn{2}{|c|}{ Code treatments }} & \multicolumn{4}{|c|}{16 hours } & \multicolumn{4}{|c|}{144 hours } \\
\hline & & Acid & Alcohol & Ester & Total & Acid & Alcohol & Ester & Total \\
\hline \multirow[t]{3}{*}{ AA } & ${ }^{\circledR} \mathrm{C}$-1-lauric acid + lauric acid & & & & & & & & \\
\hline & $\mathrm{cpm}$ & 20486 & 188 & 189 & 20863 & 16298 & 88 & 95 & 16481 \\
\hline & $\%$ & 98.2 & 0.9 & 0.9 & 100 & 98.9 & 0.5 & 0.6 & 100 \\
\hline \multirow[t]{3}{*}{ BA } & ${ }^{14} \mathrm{C}-1$-lauric acid + lauryl alcohol & & & & & & & & \\
\hline & cpm & 3467 & 254 & 240 & 3961 & 1615 & 120 & 220 & 1955 \\
\hline & $\%$ & 87.5 & 6.4 & 6.1 & 100 & 82.6 & 6.1 & 11.3 & 100 \\
\hline \multirow[t]{4}{*}{ CA } & ${ }^{14} \mathrm{C}$-1-lauric acid + methyl laurate & & & & & & & & \\
\hline & cpm & 5036 & 121 & 81 & 5238 & 1612 & 79 & 54 & 1745 \\
\hline & $\%$ & 96.2 & 2.3 & 1.5 & 100 & 92.4 & 4.5 & 3.1 & 100 \\
\hline & average $\%$ & 94.0 & 3.2 & 2.8 & & 91.3 & 11.1 & 5.0 & \\
\hline \multirow[t]{3}{*}{$\mathrm{AB}$} & ${ }^{14} \mathrm{C}$-1-lauryl alcohol + lauric acid & & & & & & & & \\
\hline & $\mathrm{cpm}$ & 147 & 2945 & 214 & 3306 & 167 & 343 & 105 & 615 \\
\hline & $\%$ & 4.5 & 89.1 & 6.5 & 100 & 27.1 & 55.8 & 17.1 & 100 \\
\hline \multirow[t]{3}{*}{ B $\underline{B}$} & ${ }^{14} \mathrm{C}$-1-lauryl alcohol + lauryl alcohol & & & & & & & & \\
\hline & cpm & 527 & 4830 & 205 & 5562 & 169 & 523 & 43 & 735 \\
\hline & $\%$ & 9.5 & 86.8 & 3.7 & 100 & 23.0 & 71.2 & 5.8 & 100 \\
\hline \multirow[t]{4}{*}{ CB } & ${ }^{14} \mathrm{C}$-1-lauryl alcohol + methyl laurate & & & & & & & & \\
\hline & $\mathrm{cpm}$ & 264 & 1267 & 210 & 1741 & 152 & 341 & 135 & 628 \\
\hline & $\%$ & 15.2 & 72.8 & 12.0 & 100 & 24.2 & 54.3 & 21.5 & 100 \\
\hline & average $\%$ & 9.7 & 82.9 & 7.4 & & 24.8 & 60.4 & 14.8 & \\
\hline \multirow[t]{3}{*}{$A \underline{C}$} & ${ }^{14} \mathrm{C}-1$-lauric acid methyl ester + & & & & & & & & \\
\hline & lauric acid $\mathrm{cpm}$ & 2923 & 509 & 1487 & 4919 & 602 & 81 & 52 & 735 \\
\hline & $\%$ & 59.5 & 10.3 & 30.2 & 100 & 81.9 & 11.0 & 7.1 & 100 \\
\hline \multirow[t]{3}{*}{$\mathrm{BC}$} & ${ }^{14} \mathrm{C}-1$-lauric acid methyl ester + & & & & & & & & \\
\hline & lauryl alcohol cpm & 1256 & 354 & 609 & 2219 & 464 & 87 & 131 & 682 \\
\hline & $\%$ & 56.6 & 16.0 & 27.4 & 100 & 68.0 & 12.8 & 19.2 & 100 \\
\hline \multirow[t]{4}{*}{ C므 } & ${ }^{14} \mathrm{C}$-1-iauric acid methyl ester + & & & & & & & & \\
\hline & methyl laurate $\mathrm{cpm}$ & 1477 & 1351 & 400 & 3228 & 497 & 86 & 28 & 611 \\
\hline & $\%$ & 45.8 & 41.8 & 12.4 & 100 & 81.3 & 14.1 & 4.6 & 100 \\
\hline & average $\%$ & 54 & 22.7 & 23.3 & & 77.1 & 12.6 & 10.3 & \\
\hline
\end{tabular}

When lauryl alcohol (BB) was used, $9.5 \%$ of the residue was found in the acid fraction and 3.7\% in the ester fraction 16 hours after treatment. Mixed application of lauryl alcohol with lauric acid $(A B)$ or methyl laurate (CB) showed a similar trend, i. e. $4.5 \%-15.2 \%$ conversion to the acid fraction, and 6.5 to $12.0 \%$ to ester fraction. These fractions converted further between 16 and 144 hours after treatment. A continued shift from alcohol fraction $(60.4 \%)$ to acid $(24.8 \%)$ and ester $(14.8 \%$ ) was observed. All fractions (ABB, $B \underline{B}$, and $\mathrm{CB}$ ) changed like this at about the same degree, indicating a consistent trend of conversion.

When lauric acid methyl ester (CC) was used, $45.8 \%$ of the ${ }^{14} \mathrm{C}$-labeling was found in the acid fraction 16 hours after application, a similar amount $(41.8 \%)$ was in the alcohol fraction, and the rest was in the ester fraction. An average decrease in the ester fraction was observed from $23.3 \%$ at 16 hours to $10.3 \%$ at 144 hours after treatment. This conversion pattern generally held under application of methyl ester mixed with either the alcohol or acid.
In all fractions further loss of radioactivity appeared 16 hours after treatment. There was significant loss in ${ }^{14} \mathrm{C}$ activity through the 144 hours' period. An earlier report (5), employing radioautograph technique, has demonstrated that a fatty compound was localized in the axillary bud area and did not translocate to any other part of the treated plant. Despite the fact that the remaining fatty materials were held by the damaged axillary tissue 16 hours after treatment, there was continued opportunity for escape or runoff. Possible microbiological degradation may have occurred during the 144 hours' observation period. However, the recovery levels reported here resulted from fresh tobacco tissue that did not undergo the curing process. Tobacco curing, during which fresh leaf is subjected to prolonged active biochemical and physical changes, would probably result in more loss and possibly further conversion of the residual fatty compounds (4). Furthermore, the application doses of fatty compounds $(1.4 \mathrm{~g})$ in this study were much higher than those for normal field application (630 to $830 \mathrm{mg}$ ). This dose was used for easier observation of the 
Table 3. Realdual tree polyol and esters from Tween used as surfactants for tobacco sucker control.

\begin{tabular}{|c|c|c|}
\hline \multirow[t]{2}{*}{ Treatments } & \multicolumn{2}{|c|}{$\begin{array}{l}\text { Residual } \\
\text { compounds in cured } \\
\text { tobacco sample } \\
(\mathrm{ppm})^{*}\end{array}$} \\
\hline & $\begin{array}{l}\text { Free } \\
\text { polyol }\end{array}$ & Esters \\
\hline Methyl laurate + Tween 20 & 120 & 3.0 \\
\hline $\begin{array}{l}\text { Methyl laurate } \\
+{ }^{14} \mathrm{C} \text {-1-fatty acid Tween } 20\end{array}$ & 216 & 3.0 \\
\hline $\begin{array}{l}\text { Methyl laurate } \\
+{ }^{14} \mathrm{C} \text {-U-ethylene oxide Tween } 20\end{array}$ & 295 & 9.5 \\
\hline Average & 210 & 5.2 \\
\hline Lauryl alcohol + Tween 80 & 131 & 5.0 \\
\hline $\begin{array}{l}\text { Lauryl alcohol } \\
+{ }^{14} \mathrm{C}-1 \text {-fatty acid Tween } 80\end{array}$ & 178 & 5.5 \\
\hline $\begin{array}{l}\text { Lauryl alcohol } \\
+{ }^{14} \mathrm{C} \text {-U-ethylene oxide Tween } 80\end{array}$ & 104 & 2.5 \\
\hline Average & 138 & 4.3 \\
\hline
\end{tabular}

"Corrected results using "hand-suckered" tobacco as background (free polyol 2 ppm, esters 4.5 ppm).

interconversion among acid, alcohol, and ester. The percentage of recovery or the residue level of fatty compounds at normal field-application levels are much lower than that observed from this elevated application level - in fact, only about $1.6 \mathrm{ppm}$ (6).

The total amount of heptane-extractable lipids in cured leaf tobacco is about $100 \mathrm{mg} / \mathrm{g}$, of which about $7 \%$ is fatty acid (4). Therefore, the fatty acid fractions natural in tobacco are about $7,000 \mathrm{ppm}$. The level of fatty compounds left on leaf tobacco because of suckering operation is, indeed, of little significance.

\section{Degradation of Tween Surfactants}

The total amount of Tween surfactants used per plant in this study was $800 \mathrm{mg}$, which was much higher than normal dosages $(320-480 \mathrm{mg})$. This was for easier detection of degraded products. As shown in Table 3 , the levels of residual esters from Tween 20 and Tween 80 were relatively low, with an average of $5.2 \mathrm{ppm}$ for Tween 20 and $4.3 \mathrm{ppm}$ for Tween 80 . The free polyol levels averaged $210 \mathrm{ppm}$ for Tween 20 and $138 \mathrm{ppm}$ for Tween $80 .{ }^{14} \mathrm{C}$-activity was not counted by our collaborators (9), but the residual data clearly indicated that nearly all the Tween surfactants found on tobaccoleaf samples had been hydrolyzed in situ to free polyol and fatty acids.

\section{SUMMARY}

The fate of fatty compounds and surfactants used for tobacco sucker inhibition was studied with ${ }^{14} \mathrm{C}$-labeled materials applied to field-grown Nicotiana tabacum L. cv. Maryland Catterton plants. Residual materials re- covered from test tobacco showed the following: [1] When lauric acid was used, the residual material was maintained essentially in the acid fraction. [2] When lauryl alcohol was used, a considerable part $(9.7-24.8 \%)$ was converted to the acid fraction, indicating possible oxidation of alcohol in the field; smaller amounts (7.4 to $14.8 \%$ ) were found in the ester fraction. [3] When methyl laurate was used, most $(54-77 \%)$ of the residue was recovered in the acid fraction, a small part (12.6 to $22.7 \%$ ) was found in the alcohol fraction, and the rest $(10.3-23.3 \%)$ remained in the ester fraction. [4] When Tween surfactants were used, nearly all the residual materials had been hydrolyzed to free polyol and fatty acids.

\section{ZUSAMMENFASSUNG}

Es wurde das Schicksal von fettartigen Verbindungen und oberflächenaktiven Substanzen, die zur Kontrolle des Geizenwachstums im Tabakanbau verwendet werden, untersucht, indem sie bei im Freiland wachsenden Pflanzen der Sorte Nicotiana tabacum L. (Maryland Catterton) als ${ }^{14} \mathrm{C}$-markierte Verbindungen angewandt wurden. Es ergaben sich im Versuchstabak folgende Rückstandsbefunde: [1] Bei Anwendung von Laurinsäure blieb der Rückstand vor allem in der sauren Fraktion. [2] Wenn Laurylalkohol verwendet wurde, wurde ein beträchtlicher Teil $(9,7-24,8 \%)$ in die saure Fraktion umgewandelt, was eine mögliche Oxidation des Alkohols während des Freilandwachstums andeutet; eine kleinere Menge $(7,4-14,8 \%$ ) fand sich in der Ester-Fraktion. [3] Bei Anwendung von Methyllaurat war der größere Teil des Rückstandes (54-77\%) in der sauren Fraktion $\mathrm{zu}$ beobachten, während ein kleiner Teil $(12,6-22,7 \%)$ in der Alkohol-Fraktion und der Rest (10,3-23,3\%) in der Ester-Fraktion verblieben. [4] Wenn oberflächenaktive Substanzen vom Typ Tween appliziert wurden, wurde fast der gesamte Rückstand zu freiem Polyol und zu Fettsäuren hydrolysiert.

\section{RESUME}

Le cheminement des composés gras et tensio-actifs utilisés comme inhibiteurs de bourgeonnement du tabac a été étudié à l'aide de composés marqués au carbone 14 sur des plantes de pleine terre de la variété Nicotiana tabacum L. (Maryland Catterton). Les résidus récupérés des tabacs étudiés ont donné les résultats suivants: [1] Quand on utilise l'acide laurique, les composés résiduels sont maintenus essentiellement dans la fraction acide. [2] Quand l'alcool laurylique est utilisé, une partie considérable (de 9,7 à 24,8\%) est transférée dans la fraction acide, indiquant peut-être une oxydation de l'alcool dans la terre; des quantites plus faibles (de 7,4 dे $14,8 \%$ ) ont été retrouvées dans la fraction estérique. [3] Quand on utilise le laurate de méthyle, on récupère de 54 a $77 \%$ dans la fraction acide, une faible partio (de 12,6 à $22,7 \%$ ) dans la fraction alcoolique, et le 
reliquat (de $10,3 \gtrsim 23,3 \%$ ) dans la fraction estérique. [4] Lorsque l'on utilise les tensio-actifs Tween, la quasitotalité des produits résiduels est hydrolysée en polyol libre et en acides gras.

\section{REFERENCES}

1. Steffens, G. L., T. C. Tso, and D. W. Spaulding: Fatty alcohol inhibition of tobacco axillary and terminal bud growth; Agr. and Food Chem. 15 (1967) 972 to 975.

2. Tso, T. C.: Plant growth inhibition by some fatty acids and their analogues; Nature 202 (1964) 511 to 512.

3. Tso, T. C.: Physiology and biochemistry of tobacco plants; Dowden, Hutchinson, and Ross, Stroudsburg, Pa., 272-281, 1972.

4. Tso, T. C., and H. Chu: Effect of growth, senescence, and curing on fatty acid composition of tobacco; Agron. J. 62 (1970) 512-514.

5. Tso, T. C., L. G. Burk, and G. L. Steffens: Localization of methyl laurate, an inhibitor of tobacco axillary bud growth; Tobacco Sci. 10 (1966) 77-80.

6. Tso, T. C., H. Chu, and D. W. DeJong: Residue levels of fatty compounds and surfactants as suckering agents on tobacco; Beitr. zur Tabakforschung 8 (1975) 241-245.
7. T'so, T. C., and J. E. McMurtrey, Jr.: Preliminary observations on inhibition of tobacco suckers by vegetable oils and fatty acids; Tobacco Sci. 7 (1963) 101 to 104.

8. Tso, T. C., G. L. Steffens, and M. E. Engelhaupt: Inhibition of tobacco axillary bud growth with fatty acid methyl esters; Agr. and Food Chem. 13 (1965) 78-81.

9. Wetteran, F. P., V. L. Olsanski, M. F. Nelson, and P. R. Fencer: Analysis of residue on tobacco leaves treated with Tweens; 1971 Report from Chemical Research Dept., ICI United States, Inc. (formerly Atlas Chemical Industries, Inc.), in a collaborative study with USDA.

\section{Acknowledgment}

We thank the ICI United States, Inc. (formerly Atlas Chemical Industries, Inc.) for providing ${ }^{14}$ C-labeled Tween surfactants and determining their residues. Also, we thank Frank Sharp and M. E. Engelhaupt for their technical assistance.

The authors' address:

Beltsville Agricultural Researd Center, Northeastem Region, Agricultural Research Service, U.S. Dept. of Agriculture, Beltsville, Maryland, 2070 s. 